\title{
Hundred legs good, two fangs better: adult centipede (Scolopendridae) devoured by a juvenile Amazon lancehead, Bothrops atrox (Viperidae)
}

\author{
Karina Maria Pereira da SILVA ${ }^{1,2 *}$, Selma Maria de ALMEIDA-SANTOS ${ }^{1}$, Rogério BERTANI ${ }^{1}$ \\ 1 Instituto Butantan, Laboratório de Ecologia e Evolução, São Paulo, SP, Brazil \\ 2 Pós-graduação em Anatomia dos Animais domésticos e Silvestres, Faculdade de Medicina Veterinária e Zootecnia, Universidade de São Paulo, USP, Av. Prof. Dr. Orlando \\ Marques de Paiva, 87 CEP 05508 270, Cidade Universitária, São Paulo, SP, Brazil \\ * Corresponding author: karina.silva@butantan.gov.br
}

\section{ABSTRACT}

Centipedes are part of the diet of several snake species of the genus Bothrops. However, reports on predation of centipedes by snakes are normally incomplete, and important data for natural history studies as the species identification and size of the prey are rarely published. The aim of this work was to report the presence of the centipede Scolopendra viridicornis in the digestive tract of the Amazon pit viper $B$. atrox. The snake specimen is an immature female from Aripuaná, state of Mato Grosso, Brazil, having a $623 \mathrm{~mm}$ snout-vent length. The centipede is an adult Scolopendra viridicornis, estimated to be 190 $\mathrm{mm}$ long, and found in the snake's stomach. The success in preying on this large and potentially dangerous centipede could be explained by the snake's dimensions, large enough for overpowering the prey, but still retaining characteristics of youth, such as venom with specific action against specific prey items.

KEYWORDS: Diet, ectothermic prey, Scolopendra.

\section{Uma centena de pernas é eficaz, mas duas presas são ainda melhores: lacraia adulta (Scolopendridae) devorada por uma jovem serpente amazônica, Bothrops atrox (Viperidae)}

\section{RESUMO}

Lacraias fazem parte da dieta de diversas espécies de serpentes do gênero Bothrops. Entretanto, informaçóes importantes para estudos de história natural, como identificação da espécie e tamanho de presas, são raramente publicados. O objetivo desse trabalho é registrar a presença de uma lacraia Scolopendra viridicornis, no trato digestivo de uma jararaca da Amazônia, Bothrops atrox. A serpente estudada é uma fêmea imatura, com $623 \mathrm{~mm}$ de comprimento rostro-cloacal, proveniente de Aripuanã, estado de Mato Grosso, Brasil. A lacraia é um adulto de Scolopendra viridicornis parcialmente digerida, com aproximadamente 190 mm de comprimento. O sucesso na predação dessa grande e perigosa presa pode ser explicado pelas dimensóes da serpente, que é grande o suficiente para dominar a presa, mas ainda retém características juvenis, como veneno com ação específica em determinados ítens alimentares.

PALAVRAS-CHAVE: Dieta, presa ectotérmica, Scolopendra. 
Most species of the genus Bothrops have a generalist diet, and some show an ontogenetic diet shift (i.e., from ectothermic to endothermic prey) (Dixon and Soini 1986; Martins and Oliveira 1998; Martins et al. 2002). The three most common prey items consumed by Bothrops spp. individuals are mammals, frogs, and lizards (Martins et al. 2002), and sometimes centipedes can be consumed as well. Information on this food item is scarce, and centipede specimens are rarely identified to genus or species level (Table 1). Centipedes (Chilopoda) are a group of terrestrial arthropods with ca. 3,300 species belonging to five orders (Edgecombe and Giribet 2007). Adult body length varies from 4 to $300 \mathrm{~mm}$, but most species have individuals measuring from 10 to $100 \mathrm{~mm}$ (Edgecombe and Giribet 2007). The species having the longest and the most aggressive individuals are in the order Scolopendromorpha, which has more than 800 valid species (Edgecombe and Giribet 2007). Of these, species in the genus Scolopendra are impressive, the Neotropical Scolopendra gigantea reaching up to $30 \mathrm{~cm}$ in length. Other species in this genus are also amongst the longest centipedes known, such as $S$. viridicornis, $S$. subspinipes, $S$. morsitans, and S. cingulata (Bücherl 1939, 1946). Individuals belonging to the large Scolopendra species are also the most aggressive centipedes (Bücherl 1946). Scolopendra cingulata, S. subspinipes and S. morsitans are Old World species, but the last two were introduced in the New World (Shelley 2006). Scolopendra viridicornis is widespread in South America, reported in Argentina, Paraguay, Bolivia, Colombia, Venezuela, Guyana, Suriname, and throughout Brazil (Shelley 2006). All centipede species are carnivorous, venomous, and normally feed on invertebrates, but larger specimens of Scolopendra spp. can also predate small vertebrates such as mice and snakes (McCormick and Polis 1982), lizards (Moura et al. 2015), and bats (Molinari et al. 2005; SrbekAraujo et al. 2012; Noronha et al. 2015). Several snakes feed on potentially dangerous prey or oversized prey (Sazima and Martins 1990; Šukalo et al. 2013; Arsovski et al. 2014). Thus, fatalities or injuries may occur, as in the case of the female Vipera ammodytes found dead, with the head of a Scolopendra cingulata protruding through the body wall of her lower abdomen (Arsovski et al. 2014).
The aim of this work was to report the presence of a large and potentially dangerous adult prey, the centipede Scolopendra viridicornis in the digestive tract of the Amazon pit viper Bothrops atrox, an equally dangerous predator. We examined an immature female Bothrops atrox (Figure 1) deposited in the herpetological collection of the Universidade Federal de Mato Grosso, Cuiabá, Brazil (UFMT 7228), 27 April 2008, from Aripuanã, state of Mato Grosso, Brazil. The specimen weighs $70 \mathrm{~g}$ and has a $623 \mathrm{~mm}$ snout-vent length, $100 \mathrm{~mm}$ tail length, and $29.62 \mathrm{~mm}$ head length. Females are considered mature if they have follicles in secondary vitellogenesis, oviductal embryos, or the presence of corpora lutea in the ovaries (Almeida-Santos et al. 2014). The female in this study showed a slender and translucent oviduct.

After dissection, we found an adult Scolopendra viridicornis in the snake's stomach. The first segments were partially digested, but the head was preserved, so that the specimen could be estimated to be $190 \mathrm{~mm}$ long, and weighed $10 \mathrm{~g}$. The prey was swallowed head-first (Table 1; Figure 1).

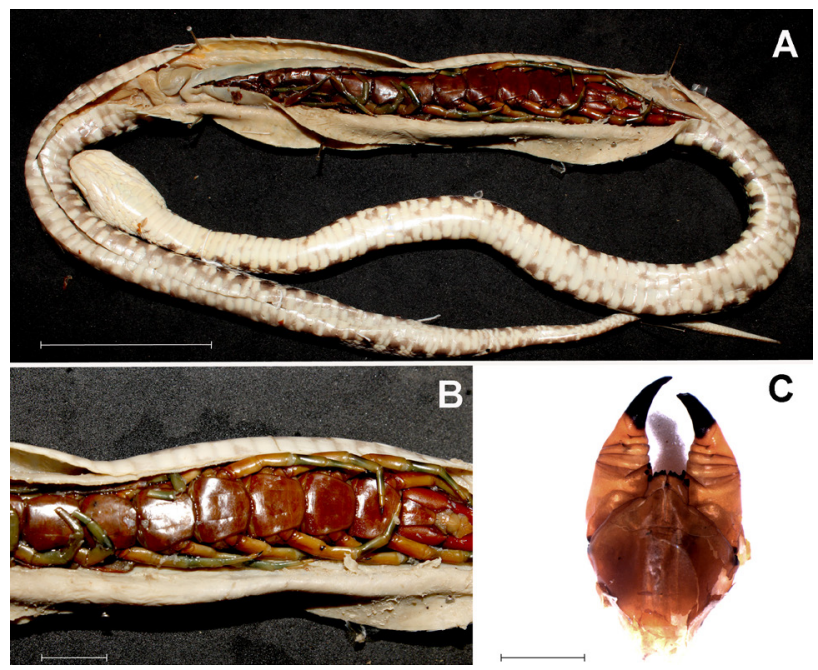

Figure 1. Scolopendra viridicornis eaten by Bothrops atrox. A. General view showing the centipede inside the dissected snake. B. Same, detail. C. Ventral view of the eaten centipede's head showing the two powerful forcipules used for venom inoculation. Scales: 1, $50 \mathrm{~mm} ; 2,10 \mathrm{~mm} ; 3,5 \mathrm{~mm}$. Photos: R. Bertani. This figure is in color only in the electronic version.

Table 1. Genera and species of centipedes identified as prey of Bothrops species. Only the records for centipedes identified at least at genus level were included.

\begin{tabular}{lccc}
\hline Snake & Locality & Centipede & Reference \\
\hline B. alcatraz & Alcatrazes Island, Brazil & Otostigmus sp. & Marques et al. 2002 \\
B. asper & Colombia & Scolopendra sp. & Greene 1992 \\
B. atrox & Iquitos, Peru & Scolopendra sp. & Dixon and Soini 1986 \\
B. atrox & Aripuanã, Mato Grosso, Brazil & Scolopendra viridicornis & This study \\
B. pauloensis & & Scolopocryptops miersi & Valdujo et al. 2002 \\
& Distrito Federal, Brazil; Minas Gerais, Brazil & Scolopendra sp. & Otostigmus sp. \\
\hline
\end{tabular}


Dixon and Soini (1986) described Scolopendra spp. individuals as part of the diet of immature snakes $B$. atrox. However, the study lacks details on prey size and maturity of the snake, even though these are important data in natural history studies. Ingestion of large prey may have some advantages, as it allows acquiring large amounts of energy at once and guards against food shortages (Sazima and Martins 1990). However, ingestion of large prey may also present risks to the snake. Despite $S$. viridicornis being a risky prey, our results indicate that the snake swallowed the centipede safely, as the stomach and guts were found intact, and part of the prey was already partially digested. This indicates that the centipede was probably poisoned to death. In the case of an aggressive prey to snakes (Arsovski et al. 2014), the effective predation is probably related to specific venom action. The small lancehead snake, Bothrops alcatraz, feeds exclusively on centipedes and lizards, and is endemic to an island in Sáo Paulo, Brazil (Marques et al, 2002; Table 1). These snakes have a venom with high procoagulant and proteolytic activity, specialized towards ectothermic prey (Furtado, 2005). Ontogenetic changes in venom take place in some snakes with a generalist diet, like B. atrox and B. asper (Dixon and Soini 1986; Greene 1992; Table 1). The venom of newborns and juveniles has higher lethal, hemorrhagic, edema-forming and coagulant activity than that of adult specimens (Saldarriaga et al. 2003). In B. jararaca the venom toxicity to frogs decreases during ontogeny, whereas venom toxicity to mice increases. The venom of Bothrops juveniles would be lethal to prey, leading to immobilization and death. In adults the venom could have a more digestive role, as they eat larger prey (Andrade and Abe 1999). The small female $B$. atrox reported herein is in the boundary between youth and maturity, when venom composition (Saldarriaga et al. 2003) and food habits change from centipedes, frogs, and lizards to rodents (Martins et al. 2002).

We conclude that the ingestion of very large centipedes is related to this short period of life, when the snake is large enough and the venom is still specific for envenoming the centipede, allowing the ingestion of this large and dangerous prey without damage to the snake. In contrast, the ingestion of very large centipedes by smaller snakes could be fatal for the snake, as described for a juvenile viper, Vipera ammodytes (Arsovski et al. 2014). This work contributes to the knowledge of the predatory and defensive behaviors of $B$. atrox, as well as the interactions between the two species and the possible role of snake venom ontogeny in the trophic relation between $B$. atrox and S. viridicornis.

\section{ACKNOWLEDGEMENTS}

We thank F.F. Curcio for allowing access to specimens under his care. KMPS was supported by a CAPES fellowship, and $\mathrm{RB}$ and SMAS received research fellow grants, respectively, from FAPESP (2015/19976-3) and CNPq.

\section{REFERENCES}

Almeida-Santos, S.M.; Braz, H.B.; Santos, L.C.; Sueiro, L.R.; Barros, V.A.; Rojas, C.A.; Kasperoviczus, K.N. 2014. Biologia reprodutiva de serpentes: recomendaçóes para a coleta e análise de dados. Herpetologia Brasileira, 3: 14-24.

Andrade, D.V.; Abe, A.S. 1999. Relationship of venom ontogeny and diet in Bothrops. Herpetologica, 55: 200-204.

Arsovski, D.; Ajtić, R.; Golubović, A.; Trajčeska, I.; Dorđević, S.; Anđelković, M.; Bonnet, X.; Tomović, L. 2014. Two fangs good, a hundred legs better: juvenile viper devoured by an adult centipede it had ingested. Ecologica Montenegrina, 1: 6-8.

Bücherl, W. 1939. Os quilópodos do Brasil. Memórias do Instituto Butantan, 13: 43-362.

Bücherl, W. 1946. Novidades sistemáticas na ordem Scolopendromorpha. Memórias do Instituto Butantan, 19: $135-158$

Dixon, J.R.; Soini, P. 1986. The reptiles of the upper Amazon basin, Iquitos region, Peru. Milwaukee Public Museum, Milwaukee, 154p.

Edgecombe, G.D.; Giribet, G. 2007. Evolutionary Biology of Centipedes (Myriapoda: Chilopoda). Annual Review of Entomology, 52: 151-170.

Furtado, M.F.D. 2005. Biological and immunological properties of the venom of Bothrops alcatraz, an endemic species of pitviper from Brazil. Comparative Biochemistry and Physiology. C, Comparative Pharmacology and Toxicology, 141: 117-123.

Greene, H.W. 1992. The ecological and behavioral context of pitviper evolution. In: Campbell, J.A.; Brodie, E.D. (Ed.). Biology of the Pitvipers. Selva, Tyler, p.107-117.

Marques, O.A.V.; Martins, M.; Sazima, I. 2002. A new insular species of pitviper from Brazil, with comments on evolutionary biology and conservation of the Bothrops jararaca group (Serpentes, Viperidae). Herpetologica, 58: 303-312.

Martins, M.; Oliveira, M.E. 1998. Natural history of snakes in forests of the Manaus Region, Central Amazonia, Brazil. Herpetology Natural History, 6: 78-150.

Martins, M.; Marques, O.A.V.; Sazima, I. 2002. Ecological and phylogenetic correlates of feeding habits in Neotropical pitvipers of the genus Bothrops. In: Schuett, G.W.; Höggren, M.; Douglas, M.E.; Greene, H.W. (Ed.). Biology of the Pitvipers. Eagle Mountain Publishing, Eagle Mountain, p.307-328.

McCormick, S.; Polis, G.A. Arthropods that prey on vertebrates. 1982. Biological Reviews, 57: 29-58.

Molinari, J.; Gutiérrez, E.E.; Ascenção, A.A.; Nassar, J.M.; Arends, A.; Márquez, R.J. 2005. Predation by giant centipedes, Scolopendra gigantea, on three species of bats in a Venezuelan cave. Caribbean Journal of Science, 41: 340-346.

Moura, L.O.G.; Machado, C.M.S.; Silva, A.O.; Conceição, B.M.; Ferreira, A.S.; Faria, R.G. 2015. Predation of Ameivulla ocellifera (Spix, 1825) (Squamata: Teiidae) in the vegetation of the Caatinga biome, northeastern Brazil. Herpetology Notes, 8: 389-391. 
Noronha, J.C; Battirola, L.D.; Chagas Júnior, A.; Miranda, R.M.; Carpanedo, R.S.; Rodrigues, D.J. 2015. Predation of bat (Molossus molossus: Molossidae) by the centipede Scolopendra viridicornis (Scolopendridae) in Southern Amazonia. Acta Amazonica, 45: 333-336.

Saldarriaga, M.M.; Otero, R.; Núñez, V.; Toro, M.F.; Díaz, A.; Gutiérrez, J.M. 2003. Ontogenetic variability of Bothrops atrox and Bothrops asper snake venoms from Colombia. Toxicon, 42: 405-411.

Sazima, I.; Martins, M. 1990. Presas grandes e serpentes jovens: Quando os olhos são maiores que a boca. Memórias Instituto Butantan, 52: 73-79.

Shelley, R.M. 2006. A chronological catalog of the New World species of Scolopendra L., 1758 (Chilopoda: Scolopendromorpha: Scolopendridae). Zootaxa, 1253: 1-50.
Srbek-Araujo, A.C.; Nogueira, M.R.; Lima, I.P.; Peracchi, A.L. 2012. Predation by centipede Scolopendra viridicornis (Scolopendromorpha, Scolopendridae) on roof-roosting bats in the Atlantic Forest of southeastern Brazil. Chiroptera Neotropical, 18: 1128-1131.

Šukalo, G.; Đorđević, S.; Dmitrović, D.; Tomović, L. 2013. Introduced fish Ameiurus nebulosus (Le Sueur, 1819): hazard to the Grass snake Natrix natrix (Laurenti, 1768). Photo note. Hyla: Herpetological Bulletin, 2: 41-42.

Valdujo, P.H.; Nogueira, C.C.; Martins, M. 2002. Ecology of Bothrops neuwiedi pauloensis (Serpentes: Viperidae: Crotalinae) in the Brazilian Cerrado. Journal of Herpetology, 36: 169-176.

Received: 02/07/2016

Accepted: 28/12/2016 